\title{
Indoor air quality assessment inside secondary public classrooms in Jeddah, Saudi Arabia
}

\author{
Areej Alama* and Mostafa Sabbagh** \\ * Department of Architecture, Faculty of Design and Architecture, Dar Al-Hekma University, , Al Fayha'a, Jeddah, Saudi Arabia \\ ** Department of Architecture, Faculty of Architecture and Planning, King Abdulaziz University, Jeddah, Saudi Arabia \\ Corresponding Author: Mjsabbagh@kau.edu.sa
}

Submitted : 16/01/2021

Revised : :19/11/2021

Accepted : 15/12/2021

\begin{abstract}
Classroom indoor air quality (IAQ) can contribute to students' wellbeing, academic performance, and quality of life. While classroom IAQ field assessments are regularly conducted globally, they are limited in the Kingdom of Saudi Arabia (KSA). Initiatives driven by Saudi Vision 2030 point toward improving IAQ conditions in classrooms and lead to the development of enhanced pilot school models. This study assesses classroom IAQ in conventional and pilot secondary public schools in Jeddah using $\mathrm{CO}_{2}$ concentration levels as a commonly used indicator for comparing IAQ and ventilation performance. $\mathrm{CO}_{2}$ levels were measured in 12 classrooms $(\mathrm{N}=12)$ that used different mechanical conditioning systems in three schools. The results revealed that all the examined classrooms reported high levels of $\mathrm{CO}_{2}$ concentrations in excess of the recommended 1,000 ppm by ANSI/ASHRAE Standard 62.1, which was mainly due to classrooms being overcrowded, the type of mechanical conditioning system, and students' behavioral patterns and operational schedules. More practical guidance on the provision of fresh air and the efficiency of mechanical ventilation systems is required to ensure adequate ventilation and pollutant dilution.
\end{abstract}

Keywords: Indoor air quality; $\mathrm{CO}_{2}$ concentration; Air conditioning; Ventilation; School classroom; Saudi Arabia.

\section{INTRODUCTION}

In schools, contaminated environments with high concentrations of $\mathrm{CO} 2$ and other gaseous pollutants can have a negative impact on students' learning, performance, and attention and can result in harmful respiratory diseases such as asthma (Cleary et al., 2017; Satish et al., 2012; The World Health Organization [WHO], 2004). WHO reported short-term health problems, infectious diseases that impacted students' attendance, and serious neurological or cancerous problems as consequences of contaminated indoor environments (WHO, 2004). The need to assess indoor air quality (IAQ) conditions in public classrooms is crucial, as schools are where kids spend most of their active time, significantly impacting their wellbeing and learning (Karapetsis and Alexandri, 2016) and where school-age populations are more sensitive to poor IAQ and environmental conditions as their immune systems are not fully developed (Antoniadou and Papadopoulos, 2017).

In addition, classrooms have a higher occupant density (occ/m2) in comparison with other types of spaces, in the range of 0.55 to $0.42 \mathrm{occ} / \mathrm{m} 2$ compared to an average of $0.1 \mathrm{occ} / \mathrm{m} 2$ for offices (Clements-Croome et al., 2008). 
For Saudi Arabia (KSA), where the population is significantly young, public schools serve $87 \%$ of students. Approximately 6.7 million out of 7.7 million attend public schools (Strategic Gears Management Consultancy, 2018). While there has been empirical research of IAQ assessments in classrooms and the impact on student health and learning (Becerra et al., 2020; Chan et al., 2020; Wargocki et al., 2020), assessments in KSA schools are limited, leading to a gap in literature reflecting the context and environment of KSA. The available local KSA studies are limited to spot measurement rather than continuous logging. Those studies did not account to the type of ventilation systems, occupant density, or reported openings position, such as windows and doors. These independent variables may have a significant impact on the measurements and outcomes. The sole use of spot measurements is not an effective or ideal method to gain an inclusive reflection of the existing conditions of $\mathrm{CO} 2$ levels in classrooms (Alsubaie, 2014; El-Sharkawy, 2014).

This study assesses IAQ and ventilation performance for classroom spaces under three different air conditioning (AC) systems typically used in school buildings in KSA. This was conducted via field observations and objective measurements of $\mathrm{CO} 2$ concentrations in secondary public schools located in Jeddah, KSA.

\section{LITERATURE REVIEW}

\subsection{Assessing IAQ in Educational Facilities}

Numerous classroom IAQ field assessments have been conducted globally, dating back to the late 1960s (Hoof, 2008). In the UK, Coley and Beisteiner (2002) investigated $\mathrm{CO}_{2}$ concentration levels in seven classrooms within four schools and demonstrated that the average $\mathrm{CO}_{2}$ level during occupied periods was $1,957 \mathrm{ppm}$, which is far beyond the recommended ANSI/ASHRAE Standard 62.1-2013 guideline of 1,000 ppm (ASHRAE, 2013). They added that the $\mathrm{CO}_{2}$ level exceeded 4,000 ppm in some classrooms. The authors reported that these classrooms have the potential to provide adequate fresh air since the supply rates measured at some periods were in line with the standard's values. However, due to staff being unaware of the problem, and due to keeping windows closed to avoid draughts, fresh air is not provided (Coley \& Beisteiner, 2002). Becerra et al. (2020) examined the levels of high-priority pollutants in 18 classrooms at nine Mediterranean schools through objective measurements. The mean $\mathrm{CO}_{2}$ concentration during teaching hours was $1,530 \mathrm{ppm}$, with peak values of 3,284 ppm in nursery and elementary schools and 5,366 ppm in secondary schools, significantly above the recommended measure. Becerra et al. reported that the indoor $\mathrm{CO}_{2}$ levels are directly impacted by the occupants and their activities and that adequate ventilation routines in classrooms are significant in lowering $\mathrm{CO}_{2}$ concentrations. Also, they highlighted that the location of schools and the surrounding outdoor pollutant sources are the main influencers on the school indoor air quality (Becerra et al., 2020). Coley et al. (2007) examined the effect of poor ventilation rates on pupils' cognitive abilities and academic performance. They reported that students' attentional processes were slower, and their concentration levels were less attentive when $\mathrm{CO}_{2}$ levels were high. Wargocki et al. (2020) studied the relationship between elementary and secondary classroom air quality represented by $\mathrm{CO}_{2}$ levels and students' learning outcomes. The results indicate that reducing $\mathrm{CO}_{2}$ levels from 2,400 to 900 ppm improved students' performance in annual national tests by $5 \%$. Additionally, reducing $\mathrm{CO}_{2}$ levels from 2,100 to 900 ppm would speed up students' performance by up to $12 \%$ and increase accuracy by $2 \%$. Students' attendance was increased by $2.5 \%$ when $\mathrm{CO}_{2}$ concentrations were reduced from 4,200 to 1,000 ppm. Chan et al. (2020) emphasized the common issue of underventilation in classrooms and inadequate indoor air quality, by measuring $\mathrm{CO}_{2}$ levels in 11 schools in California (total of 104 classrooms) retrofitted with new HVAC systems. Many other studies reported the same outcomes, highlighting the negative impacts of poor ventilation rates and high $\mathrm{CO}_{2}$ levels on students' cognitive abilities, attendance, health, and wellbeing (Cleary et al., 2017; Satish et al., 2012).

However, a limited number of studies have been conducted within the KSA and its surrounding regions. Two studies in Dammam City focused on IAQ in elementary schools (Alsubaie, 2014; El-Sharkawy, 2014). Alsubaie 
(2014) studied a total of 16 governmental schools (12 formal public-school buildings; built by the government for the purpose of education, and 4 rented buildings; designed for other uses then retrofitted into schools by the government). In each school, 4 sampling points inside classrooms and 1 sampling point outside classrooms were selected. Studied classrooms were divided into three categories, that is, those that are located directly on the playgrounds, those that are located on branched streets, and those that are located on main streets. $\mathrm{CO}_{2}$ levels were measured during two periods of one school day: from 8 to 9 am and from 10 to 11 am. El-Sharkawy (2014) studied 36 primary schools ( 26 formal public schools, and 10 rented). Four classes in each school were randomly selected for the measurements of $\mathrm{CO}_{2} . \mathrm{CO}_{2}$ levels were measured at two time intervals (9:00 am and 12:00 pm) five times at five different points in each classroom. Generally, both reported high levels of $\mathrm{CO}_{2}$ in excess of the 1,000 ppm recommended limit in all schools. Some contradictory results were found regarding $\mathrm{CO}_{2}$ concentrations in different types of public schools. Alsubaie (2014) reported that formal public-school buildings, built by the government for the purpose of education, had better $\mathrm{CO}_{2}$ levels compared to rented buildings, designed for other uses and then retrofitted into schools by the government (at $1,198.5 \pm 303.6 \mathrm{ppm}$ and $1,563.3 \pm 5,95.7 \mathrm{ppm}$ during morning periods, respectively, and 1,333.9 $\pm 475.4 \mathrm{ppm}$ and $1,780.4 \pm 636.5 \mathrm{ppm}$ during noon periods, respectively). He claims that this is probably because classrooms in formal public schools are larger and have more than one large window when compared to classrooms in rented buildings. El-Sharkawy (2014) found the opposite: the mean $\mathrm{CO}_{2}$ levels were higher in formal public schools $(1,597 \pm 245.5 \mathrm{ppm})$ than in rented buildings $(1,363 \pm 292 \mathrm{ppm})$ because of poor ventilation and the increased number of students, and because rented schools are usually located on secondary roads away from heavy traffic. This contradiction in findings reveals that $\mathrm{CO}_{2}$ concentration is not completely dependent on the type of school building (formal or rented), but rather it is influenced by other significant variables with more profound effects such as occupant density and mechanical AC types.

A study in Riyadh City, KSA, investigated IAQ in classrooms in middle schools to estimate bacterial contamination and health hazards to create standards for IAQ control (Al-Mijalli, 2016). The highest concentrations of bacterial contamination were observed in public schools, where classrooms are usually more crowded than those in private schools. This demonstrates that the lack of cleaning of AC systems may allow microbial growth, which can transmit several diseases to occupants. In Jeddah, an experimental study was conducted in university classrooms to test the essential impact of indoor $\mathrm{CO}_{2}$ levels on students' cognitive performance (Ahmed, 2017). It revealed that exposure to $\mathrm{CO}_{2}$ concentrations of $1,000 \mathrm{ppm}$ and $1,800 \mathrm{ppm}$ deteriorated accuracy rates in performing memory and attention tasks, compared to being exposed to $\mathrm{CO}_{2}$ concentrations of $600 \mathrm{ppm}$ (Table 1 compares the reviewed studies of IAQ assessments in KSA). Assessments of IAQ in classrooms within KSA under similar conditions are quite limited in their number and level of details, meaning that further field assessments are well needed.

Table 1. Comparison of the reviewed studies of IAQ assessments in KSA.

\begin{tabular}{|l|l|l|l|l|}
\hline & \multicolumn{1}{|c|}{ Study \# 1 } & \multicolumn{1}{c|}{ Study \# 2 } & \multicolumn{1}{c|}{ Study \# 3 } & \multicolumn{1}{c|}{ Study \# 4 } \\
\hline Author, Year & El-Sharkawy, 2014 & Alsubaie, 2014 & Al-Mijalli, 2016 & $\begin{array}{l}\text { Ahmed, Mumovic \& } \\
\text { Ucci, 2017 }\end{array}$ \\
\hline Location & $\begin{array}{l}\text { Dammam, Saudi } \\
\text { Arabia }\end{array}$ & $\begin{array}{l}\text { Eastern Province, } \\
\text { Saudi Arabia }\end{array}$ & Riyadh, Saudi Arabia & Jeddah, Saudi Arabia \\
\hline $\begin{array}{l}\text { Aim of Study/ } \\
\text { Hypothesis }\end{array}$ & $\begin{array}{l}\text { levels inside } \\
\text { governmental } \\
\text { elementary schools in } \\
\text { Dammam, \& the } \\
\text { study factors } \\
\text { affecting those levels }\end{array}$ & $\begin{array}{l}\text { To assess the } \\
\text { ventilation rates in } \\
\text { primary schools in } \\
\text { the Eastern Province } \\
\text { by using CO2 as an } \\
\text { indicator of } \\
\text { ventilation }\end{array}$ & $\begin{array}{l}\text { Determining groups } \\
\text { of indoor bacteria is } \\
\text { necessary for } \\
\text { estimating health } \\
\text { hazards and creating } \\
\text { standards for indoor } \\
\text { air quality control }\end{array}$ & $\begin{array}{l}\text { Temperature and } \\
\text { indoor CO2 levels } \\
\text { have an essential } \\
\text { impact on occupant's } \\
\text { cognitive } \\
\text { performance (mental } \\
\text { activities) }\end{array}$ \\
\hline
\end{tabular}




\begin{tabular}{|c|c|c|c|c|}
\hline Scope of Study & $\begin{array}{l}\text { IEQ parameters: } \\
\text {-Temperature } \\
\text {-Relative humidity } \\
\text {-Air pollutants (CO2, } \\
\mathrm{CO}, \mathrm{NO} 2, \mathrm{SO} 2, \mathrm{TSP} \text {, } \\
\text { Benzene) }\end{array}$ & $\begin{array}{l}\text { IEQ parameters: } \\
\text {-Ventilation rate } \\
\text {-CO2 concentration }\end{array}$ & $\begin{array}{l}\text { IEQ parameter: } \\
\text {-IAQ }\end{array}$ & $\begin{array}{l}\text { IEQ parameters: } \\
\text {-Temperature } \\
\text {-Humidity } \\
\text {-Air velocity } \\
\text {-CO2 concentration }\end{array}$ \\
\hline Selected Sample & $\begin{array}{l}\text {-Total of } 16 \\
\text { governmental schools } \\
\text { (12 governmental- } \\
\text { constructed, } 4 \text { rented) } \\
\text {-The selected number } \\
\text { of each type was } \\
\text { based on an equal } \\
\text { percent from the total } \\
\text { number of each } \\
\text { school type (random } \\
\text { statistical sampling) }\end{array}$ & $\begin{array}{l}\text {-Total of } 144 \text { classes } \\
\text { in } 36 \text { primary schools } \\
\text { ( } 26 \text { governmental, \& } \\
10 \text { rented) } \\
\text {-All selected schools } \\
\text { were built before } \\
2008 \text {, and all } \\
\text { examined classrooms } \\
\text { have a single wall \& } \\
\text { more than one } \\
\text { operable window }\end{array}$ & $\begin{array}{l}252 \text { samples of } \\
\text { indoor air and air } \\
\text { conditioners of } 25 \\
\text { Middle Schools } \\
\text { Public and Private, } \\
\text { were collected from } \\
\text { east and center of } \\
\text { Riyadh in, Saudi } \\
\text { Arabia, between } \\
\text { October and } \\
\text { November } 2015\end{array}$ & $\begin{array}{l}\text { In a female university } \\
\text { in Jeddah, } 499 \text { adult } \\
\text { female students were } \\
\text { tested in } 2 \text { identical } \\
\text { classrooms located in } \\
\text { central areas inside } \\
\text { the building, away } \\
\text { from external heat } \\
\text { radiation }\end{array}$ \\
\hline Research Method & $\begin{array}{l}\text {-Indoor air quality } \\
\text { physical } \\
\text { measurements }\end{array}$ & $\begin{array}{l}\text {-Indoor air quality } \\
\text { physical } \\
\text { measurements }\end{array}$ & $\begin{array}{l}\text {-Sampling and testing } \\
\text { samples in the } \\
\text { automated microbial } \\
\text { identification system } \\
\text { (VITEK 2) }\end{array}$ & $\begin{array}{l}\text {-Experiential } \\
\text { conditions } \\
\text {-Cognitive } \\
\text { assessment tests } \\
\text {-Subjective } \\
\text { questionnaire }\end{array}$ \\
\hline $\begin{array}{l}\text { Measurement } \\
\text { procedure \& } \\
\text { Duration }\end{array}$ & $\begin{array}{l}\text {-In each school, } 4 \\
\text { sampling points } \\
\text { inside classrooms \& } 1 \\
\text { sampling point } \\
\text { outside classrooms } \\
\text { were selected. } \\
\text {-Studied classrooms } \\
\text { were divided into } \\
\text { three categories; } \\
\text { those that are located } \\
\text { directly on the } \\
\text { playgrounds, those } \\
\text { that are located on } \\
\text { branched streets and } \\
\text { those that are located } \\
\text { on main streets. } \\
\text {-Pollutants were } \\
\text { measured during two } \\
\text { periods of one school } \\
\text { day; from ( } 8 \text { to } 9 \text { am) } \\
\text { and (10 to } 11 \text { am) }\end{array}$ & $\begin{array}{l}\text {-Four classes in each } \\
\text { school were } \\
\text { randomly selected for } \\
\text { the measurements of } \\
\mathrm{CO} 2 \\
\text {-CO2 rates were } \\
\text { measured at two-time } \\
\text { intervals ( } 9: 00 \text { am } \\
\text { and 12:00 pm) five } \\
\text { times at five different } \\
\text { points in each } \\
\text { classroom. Mean } \\
\text { CO2 levels were } \\
\text { calculated. }\end{array}$ & $\begin{array}{l}\text {-Collection of air } \\
\text { sampler } \\
\text { about one meter } \\
\text { above floor level. } \\
\text {-Cotton swabs were } \\
\text { collected from filters } \\
\text { of each air- } \\
\text { conditioning used } \\
\text {-Cultural media } \\
\text { samples were studied } \\
\text { in isolation }\end{array}$ & $\begin{array}{l}\text { - } 499 \text { female students } \\
\text { were exposed to } 9 \\
\text { different conditions } \\
\text { combining } \\
\text { temperatures }\left(20^{\circ} \mathrm{c} \text {, }\right. \\
\left.23^{\circ} \mathrm{c}, 25^{\circ} \mathrm{c}\right) \text { \& } \mathrm{CO} 2 \\
\text { levels }(600,1000, \\
1800 \mathrm{ppm}) . \text { Then } \\
\text { they performed } 8 \\
\text { cognitive tests. } \\
\text {-Testing took place } \\
\text { every day from } \\
\text { Saturday to } \\
\text { Wednesday for } 5 \\
\text { weeks same time of } \\
\text { day under same } \\
\text { conditions in } 2 \\
\text { identical central } \\
\text { classrooms. } \\
\text { Cognitive assessment } \\
\text { started after } 20 \text { min } \\
\text { from entry time, and } \\
\text { lasted for } 35 \text { minutes }\end{array}$ \\
\hline
\end{tabular}




\begin{tabular}{|c|c|c|c|c|}
\hline & & & & $\begin{array}{l}\text {-Subjective } \\
\text { questionnaires were } \\
\text { collected after they } \\
\text { finished }\end{array}$ \\
\hline $\begin{array}{l}\text { IEQ Standards used } \\
\text { for Assessment }\end{array}$ & $\begin{array}{l}\text {-AQGs } \\
\text {-WHO Guidelines for } \\
\text { Air Quality } \\
\text {-EPA } \\
\text {-NAAQS } \\
\text {-OSHA }\end{array}$ & $\begin{array}{l}\text {-ASHRAE } 62 \text { (2010) } \\
\text {-WHO }\end{array}$ & - & $\begin{array}{l}\text { Cognitive assessment } \\
\text { tests: } \\
\text {-Continues } \\
\text { Performance Test } \\
\text { (CPT) for testing } \\
\text { attention tasks } \\
\text {-Match to Sample } \\
\text { (MTS) for testing } \\
\text { memory tasks }\end{array}$ \\
\hline Key Findings & $\begin{array}{l}\text {-The mean levels of } \\
\text { all pollutants outside } \\
\text { schools, except } \mathrm{CO} 2 \text {, } \\
\text { were slightly higher } \\
\text { than those indoor } \\
\text {-The mean level of } \\
\mathrm{CO} 2 \text { inside schools } \\
\text { was higher than its } \\
\text { outdoor level } \\
\text {-The highest levels of } \\
\text { all pollutants were } \\
\text { inside classrooms } \\
\text { located on the } \\
\text { moderate traffic } \\
\text { streets compared with } \\
\text { low traffic ones }\end{array}$ & $\begin{array}{l}\text {-Only four schools } \\
(10 \%) \text { of tested } \\
\text { schools had } \mathrm{CO} 2 \\
\text { levels within } \\
\text { ASHRAE } \\
\text { recommended rate } \\
(1000 \mathrm{ppm}) \text {. The rest } \\
\text { of schools had high } \\
\mathrm{CO} 2 \text { levels exceeding } \\
\text { standards. This } \\
\text { indicates poor } \\
\text { ventilation rates. } \\
\text {-The average CO2 } \\
\text { levels were higher in } \\
\text { rented schools than } \\
\text { governmental ones }\end{array}$ & $\begin{array}{l}\text {-Highest level of } \\
\text { bacterial } \\
\text { contamination was } \\
\text { detected in the } \\
\text { classrooms during } \\
\text { lessons. High } \\
\text { concentrations of } \\
\text { bacteria were } \\
\text { observed in the public } \\
\text { schools (where } \\
\text { overcrowded } \\
\text { classrooms). } \\
\text {-Lack of cleaning and } \\
\text { of the HVAC may } \\
\text { allow microbial } \\
\text { growth, which causes } \\
\text { several diseases in the } \\
\text { users. }\end{array}$ & $\begin{array}{l}\text {-Effect of temp. on } \\
\text { accuracy vary } \\
\text { depending on task } \\
\text {-CO2 level has a } \\
\text { huge impact on } \\
\text { accuracy performance } \\
\text { of all tasks } \\
\text {-Cold, hot and warm } \\
\text { sensations negatively } \\
\text { impact mental } \\
\text { performance for } \\
\text { attention \& memory } \\
\text { tasks. } \\
\text {-Moderate cooling } \\
\text { sensation improved } \\
\text { mental alertness }\end{array}$ \\
\hline Abbreviation & \multicolumn{2}{|c|}{$\begin{array}{l}\text { ASHRAE: The American Society of Heating, } \\
\text { Refrigerating and Air-Conditioning Engineers } \\
\text { CBE: Center for the Built Environment - } \\
\text { Survey Model } \\
\text { TSP: Total Suspended Particles } \\
\text { AQGs: Air Quality Guidelines }\end{array}$} & \multicolumn{2}{|c|}{$\begin{array}{l}\text { WHO: World Health Organization } \\
\text { EPA: Environmental Protection Agency } \\
\text { NAAQS: National Ambient Air Quality } \\
\text { Standards } \\
\text { OSHA: Occupational Safety and Health } \\
\text { Administration }\end{array}$} \\
\hline
\end{tabular}

\subsection{Classroom Typology of Public Schools in KSA}

Early formal school building layouts consisted of three floors with classrooms lining a single-loaded corridor. This layout was further developed to include a courtyard that is utilized as a large, protected space for morning assembly and recess. School buildings consist of three floors and are utilized as follows. The ground level is usually reserved for administration offices, laboratories, and the library. The two upper levels are reserved for classrooms 
and sometimes for teachers' offices (Alzahrani, 2018). A 2.5-meter shaded arcade connects the rooms surrounding the central courtyard, and all classrooms have mechanical AC. Although all classrooms face outward, windows cannot be fully opened for safety, privacy, and security-related reasons (Khafaji, 1987).

\subsection{Occupant Density: Design Versus Operation}

Based on the design criteria of the Ministry of Education, KSA, the targeted student occupant density for an urban center such as Jeddah is a maximum of 25 students per classroom area of $43.12 \mathrm{~m} 2$ (1.3 $\mathrm{m} 2$ per student). These limits are not easily met because of rapid population growth, which is reflected in enrollment increases that are disproportionate to the growth in the number of schools. According to statistics reported by the Jeddah Office of Education, public schools are currently operating with an average of 37 students per classroom area of $45 \mathrm{~m} 2$ (Office of Education-North Jeddah, 2019). This indicates that the current operational occupant density rate in public classrooms is $0.82 \mathrm{occ} / \mathrm{m} 2$, which is significantly higher than the targeted density rate of $0.58 \mathrm{occ} / \mathrm{m} 2$.

Assessment studies conducted in public schools in KSA have concurred that classrooms are overcrowded and that their occupant density is higher than the designated rate. Al-Mijalli (2016) assessed IAQ in intermediate schools in Riyadh City and reported that, on average, there were 40 to 53 students per classroom, exceeding the designated recommended occupant count of 25 students per class. Similarly, El-Sharkawy (2014) assessed elementary classrooms in KSA's Eastern Province and reported an average number of 34 students per classroom.

\subsection{AC in Public Schools}

AC was introduced into classrooms in three stages. Window-type ACs were first to be introduced and were gradually replaced by a split AC system. However, Window-type ACs are still in use in some conventional schools. Each classroom is typically equipped with two window-type ACs or split AC units. In pilot schools, central AC systems are used, with a type of Constant Air Volume (CAV). The airflow rate was neglected. The rate of the supplied fresh air was not measured but assumed to be as per the standard design requirements. AC system types are illustrated in Figure 1.
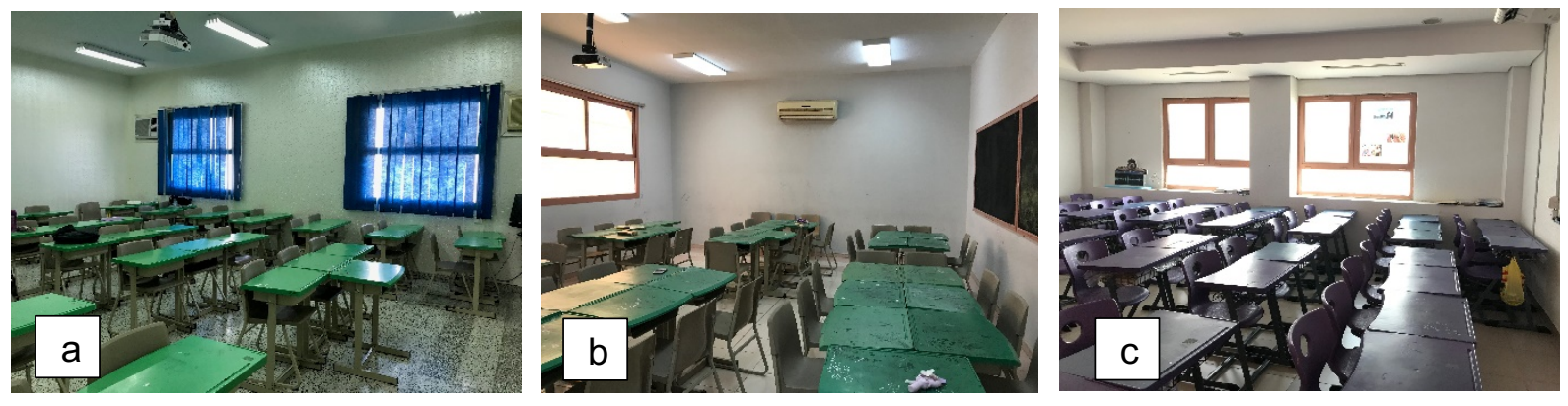

Figure 1. Three types of AC systems used in formal public schools.

Figure 1(a). Conventional window-type AC.

Figure 1(b). Conventional split AC. Figure 1(c). Pilot central AC. 


\subsection{Classroom Window and Door Use Patterns}

El-Sharkawy (2014) indicated that, because of the hot climate that characterizes most cities in KSA, classroom windows stay almost completely closed and are not used. He reported that there was no correlation between the level of $\mathrm{CO}_{2}$ and the number or size of windows. Therefore, the level of air pollutants and $\mathrm{CO}_{2}$ concentration depends mainly on mechanical ventilation (El-Sharkawy, 2014).

\section{MATERIAL AND METHODS}

\subsection{Investigated Classrooms' Conditions}

A total of 12 classrooms were chosen for the assessment, four from each school. The classrooms were chosen following several criteria: (a) occupied most of the school day; (b) have an area ranging between 42 to $48 \mathrm{~m} 2$ with a ceiling height of $3.3 \mathrm{~m}$; (c) occupied by secondary level students (grades 11 and 12) to unify the occupant body size and metabolic rate, which eventually impacts $\mathrm{CO} 2$ levels; and (d) classrooms with similar occupant density.

\section{2 $\mathrm{CO}_{2}$ Measurement Procedure and Standard Requirements}

As an indication of IAQ, $\mathrm{CO}_{2}$ levels were measured. There was a minimum logging amount of two continuous school days, reporting $\mathrm{CO}_{2}$ concentration build-up and cleanup patterns (consistent with standard BS EN 15251 requirements [The British Standards Institution], 2007). Some measurements were longer and were extended through the weekend. Field observations, along with the objective measurements, were conducted from October 28 to November 11, 2019.

$\mathrm{CO}_{2}$ concentration levels were measured using the Onset HOBO MX1102A logger. Measurements were taken in the sampled classrooms, atriums, and outdoors. In each of the three examined schools, six data loggers were installed: four in classrooms, one in the internal atrium, and one outdoors, shaded, away from people, cars, sun, heat, and rain. The loggers that were installed indoors assessed the IAQ of those selected spaces, while the outdoor logger was essential in measuring the ambient conditions to set a baseline for comparison with the internal atrium and classrooms to determine ventilation effectiveness.

Following the ANSI/ASHRAE Standard 62.1-2013 (ASHRAE, 2013), sensors in classrooms were positioned away from the diffusers' airstreams, perimeter walls and windows, and radiating heat at a height of $1.1 \mathrm{~m}$ (at the head height of a seated person) in accordance with the ANSI/ASHRAE Standard 55 (2017). As the examined classrooms were overcrowded, instead of being positioned in a central location, the instruments were installed on the board wall and as far away as possible from students' breath. Logged measurements were taken at five-minute intervals.

\subsection{Background of the Selected Samples}

The school day began at 07:00 with the first teaching period and ended between 13:30 to 14:00, depending on the day of the week. For all cases, fluctuating occupant build-up was noticed during the first period of the day due to students' arrival, during recess, and during the activity session (fourth teaching period). The student count also fluctuated for a duration of five minutes when they transitioned between class periods. In conventional classrooms with split AC units, the mode of study was lecture-based, where students are not fixed to a single class and are required to shift between rooms, based on the subject.

In the conventional classrooms with window-type $\mathrm{AC}$ units and the pilot classrooms with central AC systems, students were assigned to fixed rooms where they spent most of their school day and only went to the laboratory for 
specific science and computer subjects. Usually, when a class is conducted in a laboratory, the assigned classroom becomes vacant.

To control the fluctuations in the occupant count, examined classrooms were monitored and observed over 15minute intervals to keep track of the occupant number. Although the occupant density for classrooms recommended by the ANSI/ASHRAE Standard $62.1-2013$ is $0.3 \mathrm{occ} / \mathrm{m}^{2}$, the maximum targeted occupant density by the Ministry of Education, $\mathrm{KSA}$, is $0.58 \mathrm{occ} / \mathrm{m}^{2}$. In the current study, the average number of examined classrooms reported a higher occupant density of $0.86 \mathrm{occ} / \mathrm{m}^{2}$, showing overcrowded settings (Table 2).

Table 2. Summary of occupant profiles in examined classrooms.

\begin{tabular}{|c|c|c|c|c|c|}
\hline \multirow{2}{*}{ Classroom } & \multirow{2}{*}{ Room Code } & \multicolumn{2}{|c|}{ Number of Occupants } & \multicolumn{2}{|c|}{ Occupant Density (occ/m²) } \\
\hline & & Median & Maximum & Median & Maximum \\
\hline \multirow{4}{*}{$\begin{array}{c}\text { Conventional } \\
\text { Split AC }\end{array}$} & $\mathrm{S} 1$ & 26 & 46 & 0.57 & 1.00 \\
\hline & $\mathrm{S} 2$ & 40 & 47 & 0.87 & 1.02 \\
\hline & $\mathrm{S} 3$ & 35 & 46 & 0.76 & 1.00 \\
\hline & S4 & 33 & 42 & 0.72 & 0.91 \\
\hline \multirow{4}{*}{$\begin{array}{c}\text { Pilot } \\
\text { Central AC }\end{array}$} & $\mathrm{C} 1$ & 35 & 44 & 0.83 & 1.05 \\
\hline & $\mathrm{C} 2$ & 33 & 34 & 0.79 & 0.81 \\
\hline & $\mathrm{C} 3$ & 33 & 33 & 0.79 & 0.79 \\
\hline & $\mathrm{C} 4$ & 32 & 47 & 0.76 & 1.12 \\
\hline \multirow{4}{*}{$\begin{array}{c}\text { Conventional } \\
\text { Window-Type } \\
\text { AC }\end{array}$} & W1 & 33 & 35 & 0.69 & 0.73 \\
\hline & W2 & 34 & 38 & 0.71 & 0.79 \\
\hline & W3 & 34 & 36 & 0.71 & 0.75 \\
\hline & W4 & 34 & 35 & 0.71 & 0.73 \\
\hline \multicolumn{2}{|c|}{ Avg. Totals } & 33.5 & 40 & 0.74 & 0.86 \\
\hline
\end{tabular}

\section{RESULTS AND DISCUSSION}

\section{1 $\mathrm{CO}_{2}$ Profiles}

Table 3 illustrates the mean $\mathrm{CO}_{2}$ concentration level in the examined classrooms during the school day. All 12 classrooms have high levels of $\mathrm{CO}_{2}$ in excess of the ANSI/ASHRAE recommended rate of 1,000 ppm. The mean $\mathrm{CO}_{2}$ is lower in the window-type AC classrooms when compared to central AC classrooms for two main reasons: (1) infiltration occurred in window-type AC classrooms because of gaps and inefficient insulation around the conditioning unit (Figure 2), and (2) open doors in the window-type AC classrooms during recess. This resulted in allowing outdoor air to penetrate and dilute the indoor $\mathrm{CO}_{2}$ concentration levels in the window-type AC classrooms. 
Table 3. Summary of $\mathrm{CO} 2$ profiles in comparison to mean occupant density in examined classrooms.

\begin{tabular}{|c|c|c|c|c|}
\hline \multirow{2}{*}{ Classroom } & \multicolumn{2}{|c|}{ CO2 Concentration (ppm) } & Mean Occupant Density in \\
& Minimum & Maximum & Mean & 0.56 \\
\cline { 2 - 4 } & 345 & 4,725 & 1,926 & 0.59 \\
\hline Conventional Split AC & 382 & 4,643 & 1,503 & 0.51 \\
\hline $\begin{array}{c}\text { Conventional Window- } \\
\text { Type AC }\end{array}$ & 344 & 2,797 & 1,453 & \\
\hline
\end{tabular}

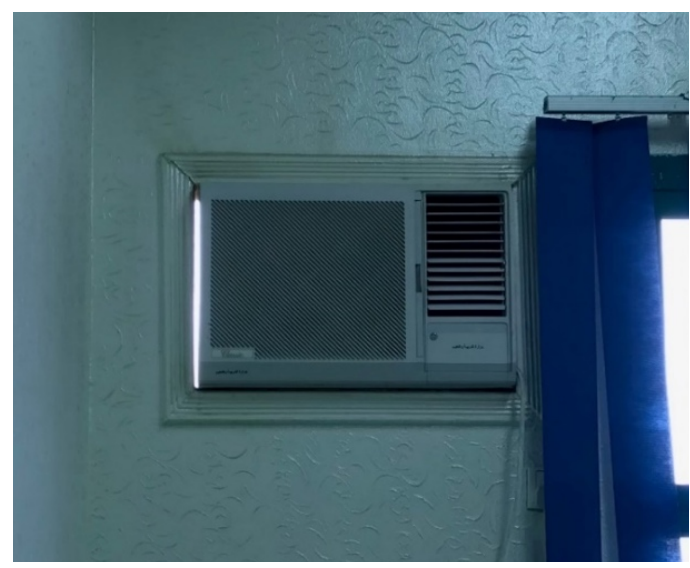

Figure 2. Infiltration gap in perimeter wall where the window-type $\mathrm{AC}$ is installed.

When investigating the time spent in classrooms where $\mathrm{CO}_{2}$ concentrations exceeded 1,000 ppm, our results show that students spend an average of $79 \%$ of their time in such classrooms. Split AC and central AC classrooms ranked highest at $81 \%$. Notably, they also recorded a slightly higher mean occupant density compared to windowtype AC classrooms (Table 4).

Table 4. Percentage of time spent in $\mathrm{CO}_{2}$ concentrations above $1,000 \mathrm{ppm}$.

\begin{tabular}{|c|c|c|c|}
\hline Classroom & $\begin{array}{c}\text { Percentage of Time Spent in } \\
\text { CO2 Concentration Above } \\
\mathbf{1 , 0 0 0} \mathbf{~ p p m}\end{array}$ & AC System & $\begin{array}{c}\text { Mean Occupant } \\
\text { Density in Examined } \\
\text { Classrooms }\end{array}$ \\
\hline Conventional Split AC & $81 \%$ & Split & 0.56 \\
\hline Pilot Central AC & $81 \%$ & Central & 0.59 \\
\hline $\begin{array}{c}\text { Conventional Window- } \\
\text { Type AC }\end{array}$ & $76 \%$ & Window & 0.51 \\
\hline Total & $79 \%$ & - & 0.55 \\
\hline
\end{tabular}


Figure 3 displays the mean, scale, and full range of the $\mathrm{CO}_{2}$ profile in all the examined classrooms. It indicates that not only did the mean $\mathrm{CO}_{2}$ concentrations exceed the recommended measure by the ANSI/ASHRAE Standard 62.1-2013 of 1,000 ppm in all 12 examined classrooms, but also the whole range exceeded this level. Split AC classrooms had the highest mean, followed by central AC and window-type AC classrooms.

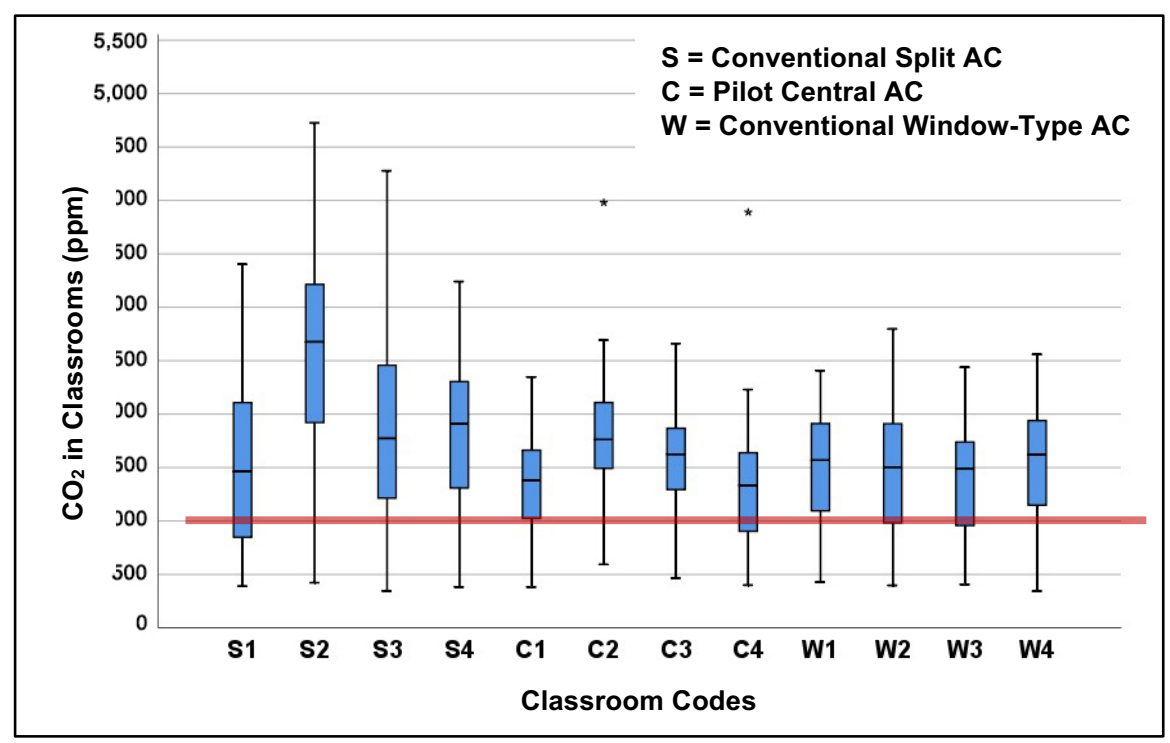

Figure 3. Box plot showing attributes and range of $\mathrm{CO}_{2}$ measurements in examined classrooms.

\subsection{Effect of Independent Variables on CO2 Concentrations}

In this study, the main independent variables were the door and window positions, mechanical ventilation types, and occupant density. Keeping track of these variables was essential as they impact the $\mathrm{CO}_{2}$ concentration levels in classrooms.

\subsubsection{Effect of Occupant Density on CO2 levels}

Occupant count, including teachers and students, in the selected classrooms was measured over 15-minute intervals. Fluctuation in occupant density was observed mostly during class transitions, recess, activity sessions, and prayer periods. The analysis of the results demonstrates that there is a strong positive correlation that is highly significant, between $\mathrm{CO}_{2}$ concentrations in classrooms and occupant density, as well as in the occupant count (Pearson's correlation $=0.775$ and 0.780 , respectively). This was recorded in all the examined classrooms, and the more the classrooms crowded with occupants, the more the $\mathrm{CO}_{2}$ levels increased, regardless of their AC types (Figure 4). The type of $\mathrm{AC}$ system had a significant influence on $\mathrm{CO}_{2}$ concentration patterns and how fast the levels increased and decreased. Figure 4 indicates that the $\mathrm{CO}_{2}$ level reached its highest concentration in the split $\mathrm{AC}$ classrooms, and the increase was more rapid. The pilot central $\mathrm{AC}$ classrooms reported the lowest $\mathrm{CO}_{2}$ level with a modest increase, indicating that it was more effective in managing space ventilation, even with high occupant density. 


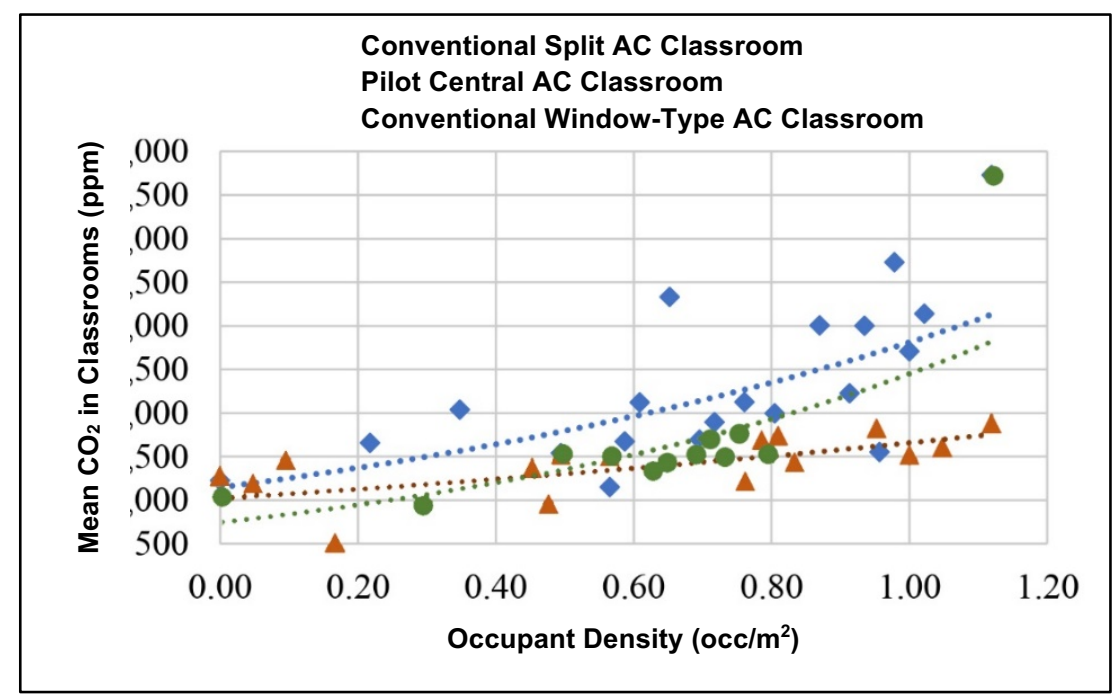

Figure 4. Scatter plot showing relationship of mean $\mathrm{CO}_{2}$ and occupant density in classrooms.

\subsection{2 $\mathrm{CO}_{2}$ Build-Up Patterns in Relation to Mechanical Conditioning Types}

The $\mathrm{CO}_{2}$ concentration profile was analyzed in each type of examined classroom. The results reveal that the AC system and the window and door positions in some cases had a significant impact on the speed of the $\mathrm{CO}_{2}$ build-up, cleanup, and peak.

This study indicates that the split $\mathrm{AC}$ and window-type $\mathrm{AC}$ classrooms experienced rapid increases in $\mathrm{CO}_{2}$ levels during their first occupied hour (Figure 5, and Figure 6). However, the increase was moderate in central AC classrooms as they are ventilated with a central $\mathrm{AC}$ system that admits fresh air (Figure 7). $\mathrm{CO}_{2}$ cleanup was slow in split $\mathrm{AC}$ classrooms and moderate in central $\mathrm{AC}$ classrooms. For the window-type $\mathrm{AC}$ systems, $\mathrm{CO}_{2}$ cleanup was quick in comparison (Figure 6); however, this was attributed to the air exchange through the doors as they were left open during recess, which helped dilute the air pollutants.

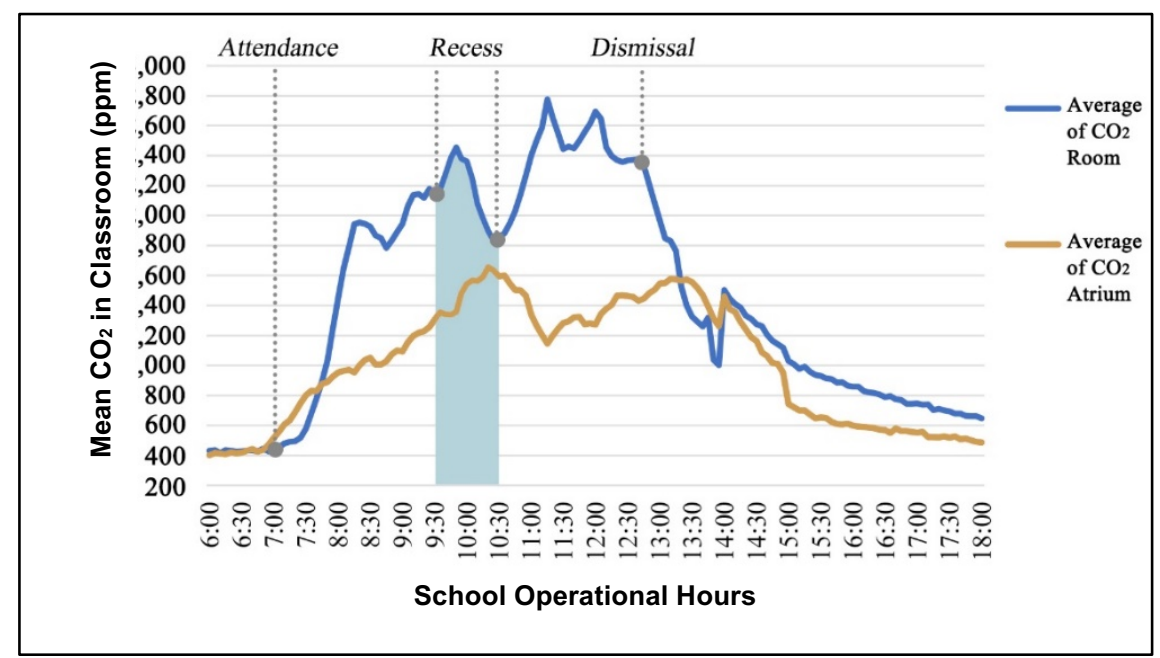

Figure 5. $\mathrm{CO} 2$ patterns in conventional split $\mathrm{AC}$ classrooms. 
1. $\mathrm{CO}_{2}$ buildup was rapid (1,300 ppm in the first occupied hour).

2. $\mathrm{CO}_{2}$ cleanup during recess was moderate $(600 \mathrm{ppm})$.

3. Peak time was at 11:15, after recess, and at the end of the fourth period (2,776 ppm).

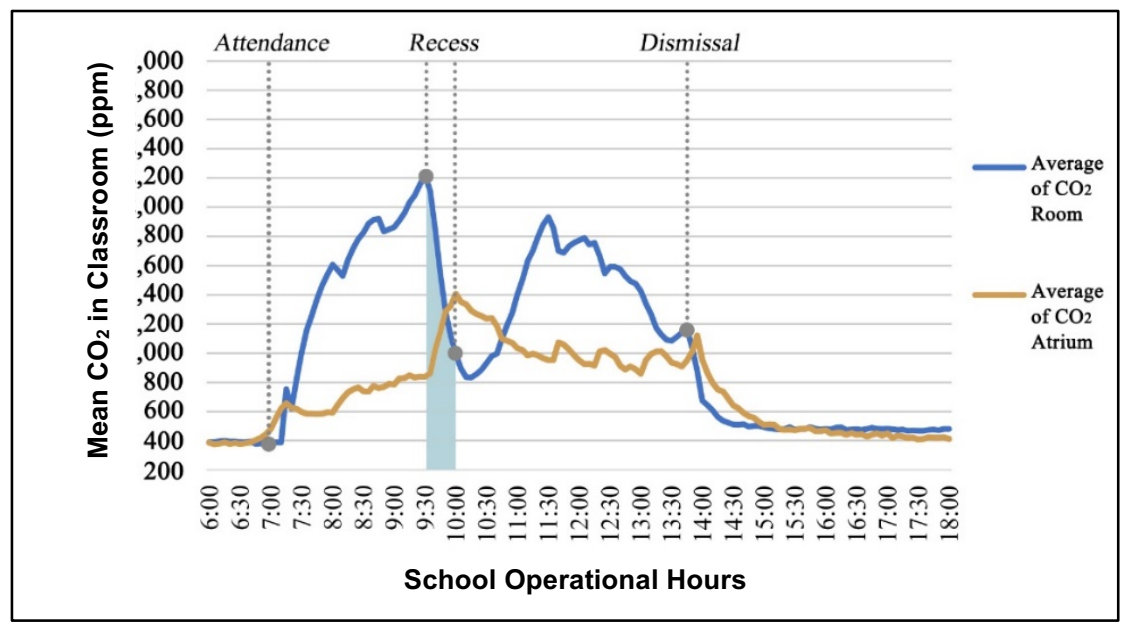

Figure 6. $\mathrm{CO}_{2}$ patterns in conventional window-type $\mathrm{AC}$ classrooms.

1. $\mathrm{CO}_{2}$ buildup was rapid (1,100 ppm in the first occupied hour).

2. $\mathrm{CO}_{2}$ cleanup during recess was rapid (1,400 ppm decrease), likely due to doors left open.

3. Peak time was at 09:30, and at the end of the third period before recess $(2,100 \mathrm{ppm})$.

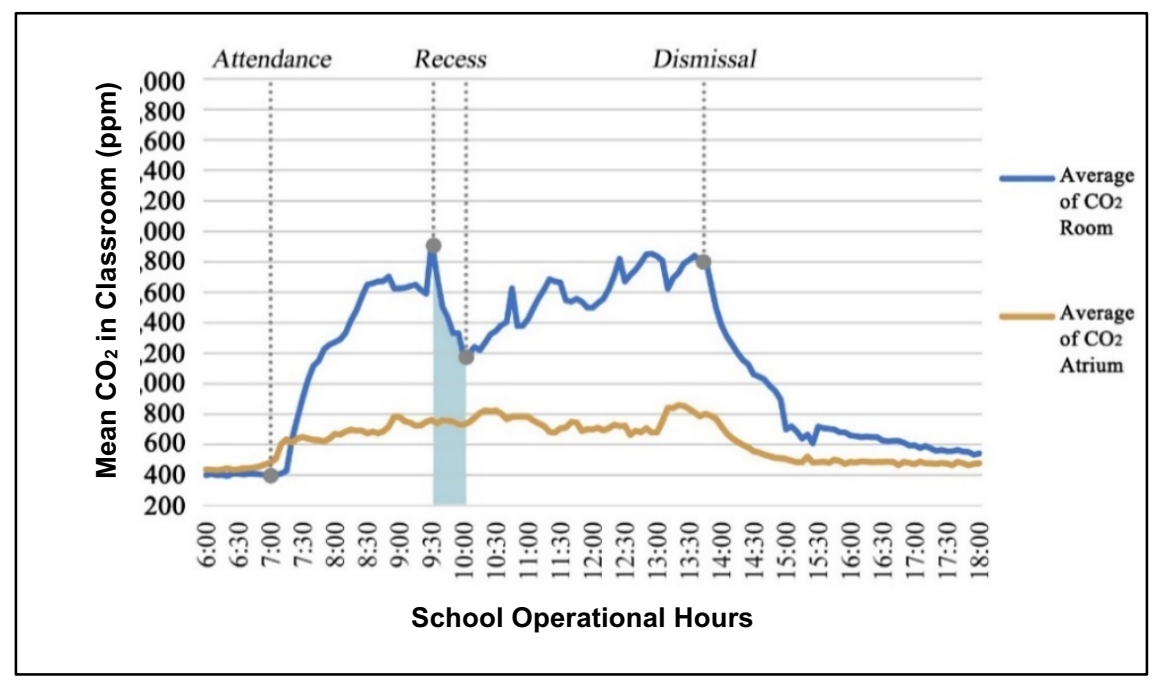

Figure 7. $\mathrm{CO}_{2}$ patterns in pilot central $\mathrm{AC}$ classrooms.

1. $\mathrm{CO}_{2}$ buildup was moderate ( $600 \mathrm{ppm}$ in the first occupied hour).

2. $\mathrm{CO}_{2}$ cleanup during recess was moderate ( $600 \mathrm{ppm}$ decrease).

3. Peak time was at 13:00, and during the last period before dismissal (1,800 ppm). 


\subsubsection{Effect of Window and Door Position on CO2 Levels}

Figure 8 illustrates the status of the mean $\mathrm{CO}_{2}$ levels in examined schools according to door position. A significant decrease exceeding $400 \mathrm{ppm}$ was reported in the conventional window-type AC classrooms when doors were open. This is because doors were left open during recess, which helped in exchanging air with the atrium. However, the recorded $\mathrm{CO}_{2}$ levels did not differ because of door positions in classrooms conditioned with either split $\mathrm{AC}$ and central AC systems, as the classroom doors were always closed during teaching periods and recess. Generally, all school doors are designed to close automatically, resulting in blocking the air movement and circulation and leaving the air unchanged and concentrated with pollutants.

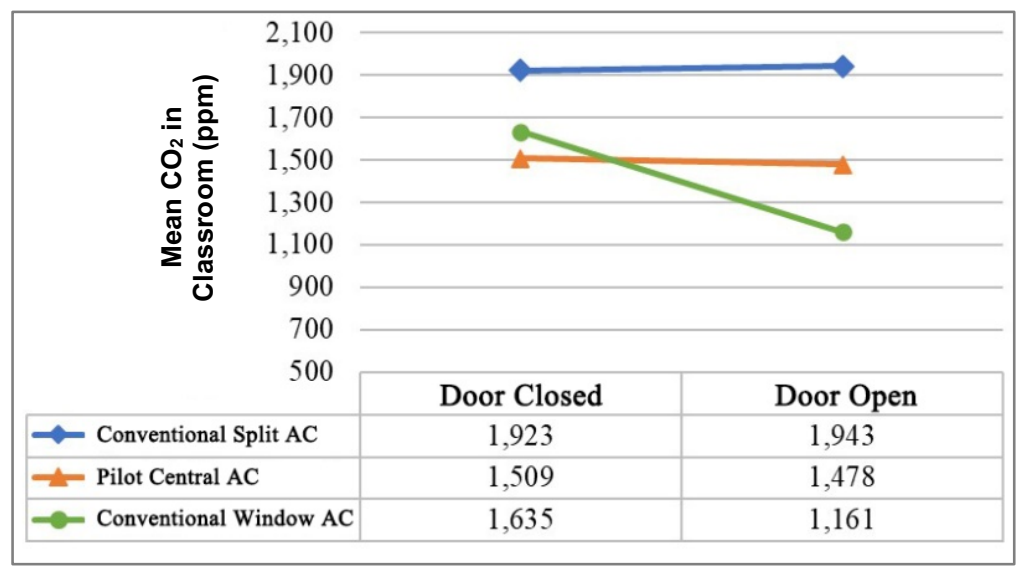

Figure 8. Mean $\mathrm{CO}_{2}$ levels in examined schools according to door positions.

To study the relationship between window positions and levels of $\mathrm{CO}_{2}$ in classrooms, only the pilot central $\mathrm{AC}$ classrooms were selected as they experienced differences in window and clerestory positions at the time of the objective measurements. Windows in the other examined classrooms were always closed during the study. Figure 9 indicates that the position of the perimeter window did not impact the levels of $\mathrm{CO}_{2}$ in the examined classrooms. This is similar to El-Sharkawy's (2014) conclusion that the indoor air pollutants are mainly impacted by the efficiency of the installed mechanical systems rather than natural ventilation, as perimeter windows are mostly closed. However, in this study, the position of the clerestory opening to the internal atrium showed a significant effect on classroom $\mathrm{CO}_{2}$ levels, with a decrease in around $250 \mathrm{ppm}$ when opened.

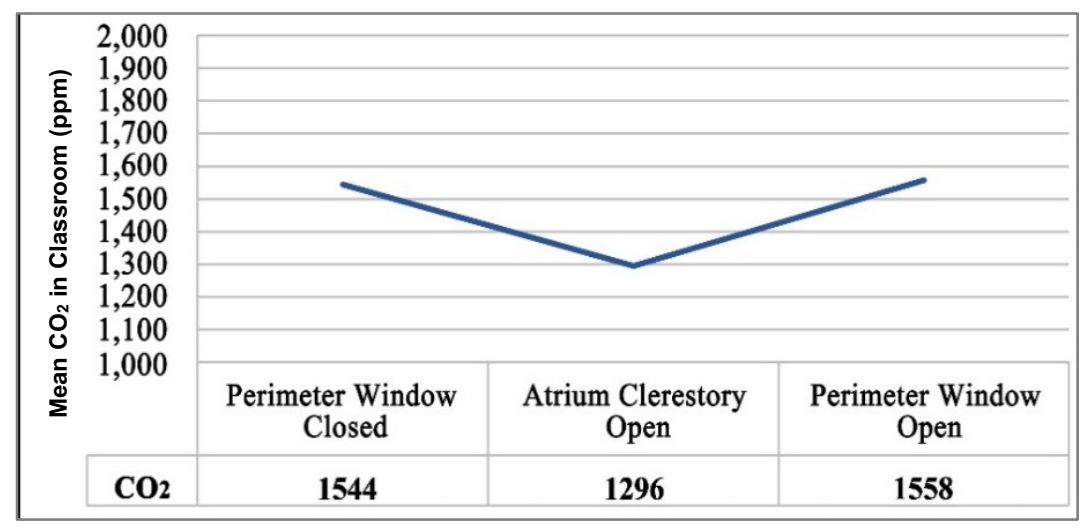

Figure 9. Classroom $\mathrm{CO} 2$ concentration levels according to window positions in pilot central AC classrooms. 


\section{CONCLUSIONS}

This study focused on the $\mathrm{CO}_{2}$ concentration levels in 12 classrooms with three AC types within three secondary public schools in Jeddah, KSA. In all of the examined classrooms and for all AC types, the reported levels of $\mathrm{CO}_{2}$ concentration exceeded the $1,000 \mathrm{ppm}$ limit recommended by the ANSI/ASHRAE Standard. Overall, an average of $79 \%$ of students' active time was spent in $\mathrm{CO}_{2}$ concentrations higher than $1,000 \mathrm{ppm}$ in the examined cases, suggesting poor IAQ. This directly reflects the lack of fresh air due to the choice of AC system, observed occupant behavioral patterns, and the increased occupant density above the spaces' designated limits. Spending long hours in such environments has significant health concerns on students' health, academic performance, comfort, and wellbeing. The build-up and cleanup patterns of $\mathrm{CO}_{2}$ levels inside classrooms with similar occupant densities were also affected by the type of AC unit installed; the highest concentrations were in split AC classrooms, and the lowest were in central AC classrooms. This is because the split AC type has no source of ventilation, whereas the central AC type is designed to have a fresh air intake and a sufficient ventilation rate through its larger diffusers. Windowtype $\mathrm{AC}$ units have no fresh air intakes but have a significant potential for infiltration because of inefficient insulation and gaps through which outdoor air can penetrate and dilute the indoor air pollutants. This indicates the effectiveness of the central $\mathrm{AC}$ system in maintaining $\mathrm{CO}_{2}$ concentrations and indoor quality measures, among other $\mathrm{AC}$ types.

Although the study shows that the position of perimeter window had no impact on $\mathrm{CO}_{2}$ concentration, there was a significant decrease in the indoor $\mathrm{CO}_{2}$ levels when the internal clerestories in the pilot classrooms were open. This decrease was also reported in the conventional window-type AC classrooms when doors were left open during recess.

The limited number of national studies assessing schools' IAQ in KSA makes this study even more important. In KSA, schools may be designed to meet the building code standards; however, during schools' operational periods, some changes are made to cope with the increasing number of enrolled students, which causes these high $\mathrm{CO}_{2}$ concentrations.

Although the conclusion represents only a sample of classrooms in secondary public schools in Jeddah, it emphasizes the essence of conducting further studies and frequent investigations on larger samples and bigger population in order to highlight concerns, generalize findings, and eventually develop solutions and regulations to ensure quality indoor air in classrooms in KSA. Our findings highlight the need to abide by national building codes and ventilation design standards that demand minimum fresh air requirements. It is essential to have tight control over student numbers in order to stay within the designated occupant limit in classrooms, as students' health and wellbeing are at stake. Creating awareness would improve students' and school administrations' behavioral patterns to achieve quality measures in their educational spaces.

\section{ACKNOWLEDGMENT}

The authors express their gratitude to the Ministry of Education (MOE), KSA, school principals, teachers, and students for facilitating access to the study and for the provision of necessary data and valuable feedback.

\section{REFERENCES}

Ahmed, R.J., Mumovic, D., Ucci, M., 2017. The effect of indoor temperature and CO2 levels on cognitive performance of adult females in a university building in Saudi Arabia. CISBAT 2017 International Conference-Future Buildings \& Districts. Energy Procedia. 122, 451-456.

https://doi.org/10.1016/j.egypro.2017.07.378 
Al Horr, Y., Arif, M., Kaushik, A., Mazroei, A., Katafygiotou, M., Elsarrag, E., 2016. Occupant productivity and office indoor environment quality: A review of the literature. Build. Environ. 105, 369-389. https://doi.org/10.1016/j.buildenv.2016.06.001

Al-Mijalli, S.H.S., 2016. Bacterial contamination of indoor air in schools of Riyadh, Saudi Arabia. Air Water Bourne Dis. 6, 131. https://doi.org/10.4172/2167-7719.1000131

Alsubaie, A.S.R., 2014. Indoor air ventilation in primary schools in Eastern Province, Saudi Arabia. Int. J. Curr. Res. 6, 6552-6557.

Alzahrani, H.M., 2018. Developing a model for assessing the effect of physical indoor environment quality on teachers' performance in Saudi educational buildings [unpublished doctoral dissertation]. University of Wolverhampton, UK.

American Society of Heating, Refrigerating, and Air-Conditioning Engineers [ASHRAE], 2013. ANSI/ASHRAE Standard 62.1-2013: Ventilation for acceptable indoor air quality. Atlanta, GA. http://www.myiaire.com/product-docs/ultraDRY/ASHRAE62.1.pdf (accessed 9 October 2019).

American Society of Heating, Refrigerating, and Air-Conditioning Engineers [ASHRAE], 2017. ANSI/ASHRAE Standard 55-2017. Thermal environmental conditions for human occupancy. Atlanta, GA. https://mafiadoc.com/ashrae-standard-55-2017_5c614e2c097c47942e8b45e9.html (accessed 9 October 2019).

Antoniadou, P., Papadopoulos, A.M., 2017. Occupants' thermal comfort: State of the art and the prospects of personalized assessment in office buildings. Energy Build. 153, 136-149.

https://doi.org/10.1016/j.enbuild.2017.08.001

Becerra, J.A, Lizana, J., Gil, M., Barrios-Padura, A., Blondeau, P., Chacartegui, R., 2020. Identification of potential indoor air pollutants in schools. J. Clean. Prod. 242, 118420. https://doi.org/10.1016/j.jclepro.2019.118420

British Standards Institution, 2007. British Standards Document BS EN 15251. Indoor environmental input parameters for design and assessment of energy performance of buildings addressing indoor air quality, thermal environment, lighting, and acoustics. 2007. https://doi.org/10.3403/30133865u

Chan, W.R., Li, X., Singer, B.C., Pistochini, T., Vernon, D., Outcault, S., Sanguinetti, A., Modera, M., 2020. Ventilation rates in California classrooms: Why many recent HVAC retrofits are not delivering sufficient ventilation. Build. Environ. 167, 106426. https://doi.org/10.1016/j.buildenv.2019.106426

Cleary, E., Asher, M., Olawoyin, R., Zhang, K., 2017. Assessment of indoor air quality exposures and impacts on respiratory outcomes in River Rouge and Dearborn, Michigan. Chemosphere. 2017:1-20. https://doi.org/10.1016/j.chemosphere.2017.08.091

Clements-Croome, D.J., Awbi, H.B., Bakó-Biró, Z., Kochhar, N., Williams, M., 2008. Ventilation rates in schools. Build. Environ. 43, 362-367. https://doi.org/10.1016/j.buildenv.2006.03.018

Coley, D.A., Beisteiner, A., 2002. Carbon dioxide levels and ventilation rates in schools. Int. J. Vent. 1, 45-52. https://doi.org/10.1080/14733315.2002.11683621

Coley, D.A., Greeves, R., Saxby, B.K., 2007. The effect of low ventilation rates on the cognitive function of a primary school class. Int. J. Vent. 6(2), 107-112. https://doi.org/10.1080/14733315.2007.11683770

El-Sharkawy, M.F.M., 2014. Study the indoor air quality level inside governmental elementary schools of Dammam City in Saudi Arabia. Int. J. Environ. Health Eng. 3, 30-37.

Environmental Protection Agency [EPA], 1989. Report to Congress on indoor air quality. Volume II: Assessment and control of indoor air pollution. EPA/400/1-89/001C. Washington, DC. 
Hoof, J.V., 2008. Forty years of Fanger's model of thermal comfort: Comfort for all? Indoor Air. 18, 182-201. https://doi.org/10.1111/j.1600-0668.2007.00516.x

Karapetsis, A., Alexandri, E., 2016. Indoor environmental quality and its impacts on health - Case study: School buildings. Proceedings of the Energy in Buildings $5^{\text {th }}$ International Conference at Athens, Greece, 78-81.

Khafaji, O.M.A.O., 1987. The provision of school buildings in Saudi Arabia with particular reference to Jeddah [PhD thesis]. University of Sheffield, UK.

Office of Education-North Jeddah, 2019. Student count for north Jeddah schools. Ministry of Education, KSA.

Rupp, R.F., Vásquez, N.G., Lamberts, R., 2015. A review of human thermal comfort in the built environment. Energy Build. 105, 178-205.

Satish, U., Mendell, M.J., Shekhar, K., Hotchi, T., Sullivan, D., Streufert, S., Fisk, W.J., 2012. Is $\mathrm{CO}_{2}$ an indoor pollutant? Direct effects of low-to-moderate $\mathrm{CO}_{2}$ concentrations on human decision-making performance. Environ. Health Perspect. 120, 1671-1677. https://doi.org/10.1289/ehp.1104789

Strategic Gears Management Consultancy, 2018. Growth Potential of Private Education in Saudi Arabia. https://www.strategicgears.com/wp-content/uploads/2018/09/Growth-Potential.pdf (accessed 10 December, 2019).

Wargocki, P., Porras-Salazar, J.A., Contreras-Espinoza, S., Bahnfleth, W., 2020. The relationships between classroom air quality and children's performance in school. Building and Environment. 173, 106749. https://doi.org/10.1016/j.buildenv.2020.106749

World Health Organization [WHO], 2004. The physical school environment: An essential component of a health-promoting school. https://apps.who.int/iris/bitstream/handle/10665/42683/9241590645.pdf?sequence=1\&isAllowed=y\&ua=1 (accessed 22 November 2019). 